\title{
Effects of Roller Massage and Static Stretching on Thigh Muscles
}

\section{Roller ile Yapılan Masaj ve Statik Germenin Uyluk Kaslarındaki Etkileri}

\author{
Ömer Batın Gözübüyük ${ }^{1}$, Can A. Yücesoy² \\ ${ }^{1}$ Sports Medicine Department, İstanbul University, İstanbul, Turkey \\ Institute of Biomedical Engineering, Bogaziçi University, İstanbul, Turkey
}

O. B. Gozubuyuk 0000-0003-0231-9376

\section{A. Yucesoy}

0000-0002-6238-4420

Geliş Tarihi/Date Received: 13.09.2018

Kabul Tarihi/Date Accepted: 21.12.2018

Yayın Tarihi/Published Online: 20.05.2019

Yazışma Adresi /

Corresponding Author: Ömer Batın Gözübüyük İstanbul Üniversitesi, Spor Hekimliği Anabilim Dalı, İstanbul, Turkey

E-mail: omer.batin@gmail.com (C)2019 Türkiye Spor Hekimleri Derneği. Tüm hakları saklıdır.

\section{ABSTRACT}

Objective: Self-myofascial release (SMR) and static stretching (SS) are common precompetition applications, aiming at relaxing muscles and surrounding fasciae. However, assessments of their effects on the targeted agonistic muscles and possible effects on antagonistic muscles are lacking. Based on myofascial force transmission, we hypothesized that effects of SMR and SS are (1) different on agonistic (knee flexors) and (2) non-trivial on the antagonistic (knee extensors) thigh muscles.

Materials and Methods: Twenty-two healthy males $(24,05 \pm 4,01$ years old) were randomly divided into two groups (SS and SMR, $n=11$ each). The groups were interchanged seven days later (cross-over design). After a stationary bicycle warm-up, isometric strength testing was performed (pre-condition), followed by the SMR or SS procedures consisted of four consequtive applications with 1 minute of durations. After 10 mins, the testing was repeated (post-condition).

Results: SS significantly increased torque increase rate (flexors, 18.4\%) and average torque (extensors, $4.9 \%$ ). SMR caused significant average torque increase (flexors, $6.6 \%$ ) and time to peak torque (extensors, 16.7\%). The change in agonists torque increase rate over time was significantly different between groups (time* interaction effect [ANOVA], $\mathrm{p}<0.05)$.

Conclusions: SMR affected force production and SS affected the speed of contraction positively for the knee flexors, and SS affected force production positively for the knee extensors. However, SMR has a negative effect on the speed of contraction of the knee extensors. Widespread effects are ascribed to myofascial force transmission. Although both are utilized for same purpose they can not be regarded as interchangeable methods.

Keywords: Myofascial release, hamstrings, quadriceps muscle, myofascial force transmission, isometric strength

\section{Öz}

Amaç: Kendi kendine yapılan miyofasyal gevşetme (MFG) ve statik germe (SG), sportif performans öncesi sıklıkla uygulanan, kaslar ile onları çevreleyen fasyayı gevşetmeyi amaçlayan iki yöntemdir. Ancak bu yöntemlerin gerek uygulama yapılan, gerekse uygulama yapılmayan kas gruplarındaki eşzamanlı etkilerini araştıran çalışmalar çok nadirdir. Miyofasyal kuvvet iletimi prensibine dayanarak, MFG ve SS'nin hem agonist (diz fleksör) kas grubundaki izometrik kuvvete olan etklilerinin birbirinden farklı olduğu, hem de antagonist kas grubunda (diz ekstansör) da anlamlı etkileri olduğu hipotezini kurduk.

Gereç ve Yöntemler: Yirmi iki sağlıklı erkek (yaş $=24,05 \pm 4,01$ ) çalışmaya alındı ve randomize olarak SG $(n=11)$ ve MFG $(n=11)$ gruplarına ayrıldı. Bir hafta sonra iki grup 
yer değiştirdi (çapraz dizayn). Deney protokolünde, katılımcılar bisikletle ısınmanın ardından izometrik kuvvet testine girdi. Ardından 1 dakikalık 4 tekrarlı SG veya MFG uyguladı. On dakika sonra izometrik test tekrarlandı.

Bulgular: Statik germe uygulama yapılan kas grubunda (fleksörler) tork artış oranında (\%18.4) ve antagonist kas grubunda (ekstansörler) ortalama torkta (\%4.9) anlamlı artışa neden oldu. Miyofasyal gevşetme ise ortalama torkta uygulama yapılan fleksör grupta anlamlı artışa (\%6.6) ve ekstansör grupta tepe tork değerine ulaşma süresinde anlamlı uzamaya (\%16.7) neden oldu. Agonist kas grubunun tork artış oranı, gruplar arasında anlamlı derecede farklı değikenlik gösterdi (zaman* grup etkileşimi [ANOVA], p<0.05).

Sonuç: Miyofasyal gevşetme, uygulama yapılan kas grubunda kuvvet üretimini, statik germe ise kasılma hızını olumlu yönde değiştirdi. Statik germe antagonist kas grubunun kuvvet üretme değerlerine de olumlu katkı sağladı. Ancak miyofasyal gevşetmenin antagonist kas grubunun kasılma hızıyla ilgili olumsuz etkileri oldu. Miyofasyal kuvvet iletimi prensibi, bu iki yöntemin farklı etkiler göstermesi ile ilgili olabilir. Her ne kadar benzer amaçlarla uygulansa da bu iki yöntemin birbinin yerine geçmediği görülmektedir.

Anahtar kelimeler: Miyofasyal gevşetme, hamstring kası, quadriceps kası, miyofasyal kuvvet iletimi, izometrik kuvvet

Available at: http://journalofsportsmedicine.org and http://dx.doi.org/10.5152/tjsm.2019.131

Cite this article as: Gozubuyuk OB, Yucesoy CA. Effects of roller massage and static stretching on thigh muscles. Turk $J$ Sports Med. 2019;54(3):183-94.

\section{INTRODUCTION}

The functionality of fascia, i.e. all the component layers are able to glide freely over one another, is crucial for movement, $(1,2)$ which may be deteriorated due to trauma, either in the form of an acute injury or microtrauma ascribed to e.g., increased physical activity. Resulting inflammation of fascial tissues may cause scar tissue formation inside fascial structure over time (3) leading to reduced pliability and a restricted intermobility of the tissue parts such as altered sliding of thoracolumbar fascial layers of patients with low back pain.(4) In overuse syndromes or after traumatic injuries, it is suggested that connective tissue could become tighter/denser. The alteration of fascial pliability could lead to distorted structural alignment of the connective tissue, decreased strength and motor coordination. $(4,5)$ Furthermore, it is considered that fascial restrictions in one part of the body can cause inharmonic stress in other regions because of the fascial continuity.(6)

Myofascial release (MFR) has been introduced as a method to ease restrictions in the fascia.(3) MFR is applied by a therapist or self applied using semi-rigid materials such as rollers, sticks etc. In this soft-tissue technique, a sustained pressure is applied into the fascia for 90-120 seconds, which facilitates a stretch. Hypothetically, the tissue then undergoes histological length changes allowing the release of the fascia.(1) Static stretching (SS) is used for similar purposes in which the muscles are held in an elongated position for a period of time until a stretch sensation or feeling of discomfort.(7) Both MFR and SS are used by athletes prior to or after sporting performance due to their potential to increase range of motion (ROM),(8-10) reduce muscle soreness,(11) improve skeletal muscle functioning and reduce injury incidence.(10, 12, 13) Although having been studied extensively, effects of SS reported differ widely. Additionally, physiological mechanisms of fascial techniques have not been elucidated adequately and their application much depends on the experience and feelings of the therapist.(14) In particular it is unclear how therapy methods involving contact and/or stretch may optimize functioning of the targeted extremity in terms of an increase in generated torque, or the speed of contraction.

Two specific issues are to be considered critically:

1-Regarding the targeted agonistic muscles, by definition, both techniques are used interchangeably, but it is not clear if they impose the same effects for a subsequent isometric contraction. 
2- Regarding the antagonistic muscles, effects of these techniques on isometric muscle force are usually dismissed, and needs to be further studied. Epimuscular myofascial force transmission (EMFT) (15) characterizes mechanical interaction between muscles of a limb due to their mutual connections via collagen reinforced connective tissue structures such as neurovascular tracts and the integral fascial structure including intramuscular and compartmental connective tissues. In animal experiments, it has been shown that EMFT occurs within the entire limb i.e., between synergistic as well as antagonistic muscles.(16) Recent studies in human muscles confirm that conclusion.(17) Although considered as a superficial intervention, kinesio taping applied over the tibialis anterior muscle was shown to affect not only this muscle but also all muscles within the limb.(18) It is conceivable that both MFR and SS techniques alter EMFT, which may affect mechanics of the extremity muscles, hence joint function.

We hypothesized that effects of a self-applied myofascial release (SMR) and static stretch (SS) on a subsequent isometric contraction are significantly different (1) on agonistic and (2) also on the antagonistic human muscles. The aim was to test these hypotheses by imposing SMR and SS on the hamstrings and quantifying the effects of these techniques using metrics obtained from knee joint torque-time traces measured in isometric contraction.

\section{METHODS}

The experiment consisted of 3 visits to sports medicine performance laboratory. The first visit was a familiarization session where anthropometric measurements were taken and subjects filled out a Short Form-36 (SF-36) form for assesing general wellbeing to avoid any emotional and phsyical limitations of participants and an International Physical Activity Questionnaire (IPAQ) to assess physical activity levels of participants in order to obtain a homogenously active, thus with a similar muscular characteristics group of patients. During the familiarization session, participants were introduced with the roller stick to be used in SMR protocol as well as the isokinetic dynamometer and the stationary bicycle for warm-up.

The second and third visits were randomly ordered for two groups; the SMR $(n=11)$ and the SS $(n=11)$ group. On the second and third visits, participants followed the same protocol, either in SMR or SS group. After arrival to the laboratory, the participants first warmed up in a stationary bicycle (Sports $\operatorname{Art}^{\circledR}, 5150 \mathrm{R}$ ) at a speed of 60-65 rpm for 10 minutes. Subsequently, the first isometric strength testing was performed (pre condition). This was followed by the SMR or SS procedure. After a 10 minutes rest in relaxed sitting position, the second isometric strength testing was performed (post condition). The second isometric testing took place after a rest period of 10 minutes for two reasons: (i) usually an additional time is needed (dressing, walking etc.) to perform after an intervention or massage, and the experimental design accommodates that.(7) (ii) In order to avoid plausible fatigue stemming from preliminary experiments.

The third visit was one week apart from the second visit, where the groups interchanged (SMR to SS or SS to SMR). All measurements were performed between 10.00 a.m. and 13.30 p.m. in order to limit fascial stiffness changes throughout the day.

\section{Subjects}

Twenty-two healthy male vounteers participated in the study (mean age $\pm \mathrm{SD}=24.05$ \pm 4.01 years [age range: $18-35$ years old], body mass index [BMI] $23.48 \pm 3.81 \mathrm{~kg} / \mathrm{m}^{-2}$ ). This number was determined by a priori power analysis using an alpha level of 0.05 and power of 0.80 using G-Power software, which resulted in a minimum of 10 participants in each group. Medical students volunteered for the study, and were recruited by study information given at the end of their sports medicine elective lectures. Nine (41\%) out of 22 subjects reported being moderately physically active and 13 (59\%) being highly physically active. On average, general wellbeing of the study group was high (Table 1). 
Table 1. Participant characteristics

\begin{tabular}{|c|c|}
\hline \multicolumn{2}{|l|}{ Sociodemographic characteristics } \\
\hline Age (mean \pm SD) & $24.05 \pm 4.01$ \\
\hline BMI (mean $\pm S D)$ & $23.48 \pm 3.81$ \\
\hline \multicolumn{2}{|l|}{ Dominant leg $(n,(\%))$} \\
\hline Right & $20(90.9)$ \\
\hline Left & $2(9.1)$ \\
\hline \multicolumn{2}{|l|}{ Physical Activity Level (n[\%])* } \\
\hline Low & $0[\% 0]$ \\
\hline Moderate & $9[\% 40.9]$ \\
\hline High & $13[\% 59.1]$ \\
\hline \multicolumn{2}{|l|}{ SF-36 Scores (mean \pm SD) ${ }^{* *}$} \\
\hline Physical Functioning & $98.18 \pm 3.63$ \\
\hline Role limitations due to physical health & $96.59 \pm 11.69$ \\
\hline Pain & $87.73 \pm 11.77$ \\
\hline General Health & $72.05 \pm 17.37$ \\
\hline Energy/fatigue & $67.5 \pm 14.12$ \\
\hline Social Functioning & $86.93 \pm 17.02$ \\
\hline Role limitations due to emotional problems & $74.24 \pm 35.53$ \\
\hline Emotional Well-being & $73.09 \pm 14.41$ \\
\hline \multicolumn{2}{|l|}{ SD: Standard deviation. SF-36: Short-form 36.} \\
\hline \multicolumn{2}{|c|}{$\begin{array}{l}\text { *Recent physical activity status of the participants, recorded via an international physical activi } \\
\text { questionnaire (IPAQ) was high }(13(59.1 \%) \text { ) and moderate }(9(40.9 \%)) \text {. }\end{array}$} \\
\hline \multicolumn{2}{|c|}{$\begin{array}{l}{ }^{* *} \text { A short form } 36 \text { (SF-36) was applied in order to evaluate the recent functional status and gener } \\
\text { wellbeing. General wellbeing of the participants, i.e., SF-36 scores were high, with 'energy, vitalit } \\
\text { having the lowest average score of } 67.5 \text {. A power analysis was conducted prior to the study. For or } \\
\text { group and two measurements, } 0.80 \text { effect size, } 95 \% \text { confidence and } 90 \% \text { power, the analys } \\
\text { revealed } 20 \text { participants. }\end{array}$} \\
\hline
\end{tabular}

All participants were free from any active local or systemic infections, any systemic or metabolic disease, history of a lower extremity injury or trauma during the last 6 months, surgery to lower limb and resistance exercise 48 hours prior to testing. Our investigations on subjects conformed the Declaration of Helsinki and approved by a Committee on Ethics of Human Experimentation at Istanbul University.

\section{Procedures}

\section{Self-myofascial release protocol}

A semi-rigid roller massager by Theraband ${ }^{\circledR}$ (The Hygenic Corporation, Akron, $\mathrm{OH}$ ) was used for the myofascial release applied to the hamstrings of the dominant leg. The roller was held in the participants' hands, as they were standing. Starting from the posterior of the knee to the ischial tuberosity it was applied with a slow pace (3 seconds for up and down, each) for 60 seconds followed by a resting period of 30 seconds (Fig. 1A). The foot was resting on a platform keeping the knee at approximately 90 . The pressure exerted was 7-8 over 10 on a Visual Analog Scale.(19) The procedure was repeated four times.(20)

\section{Static stretch protocol}

In sitting posture on an examination bed, the participants stretched their dominant leg by extending the knee as they bent their trunk forward for 60 seconds followed by a resting period of 30 seconds (Fig. 1B). The tension felt as reported by the participants was 7-8 over 10 on a VAS scale.(8) The procedure was repeated 4 times. 

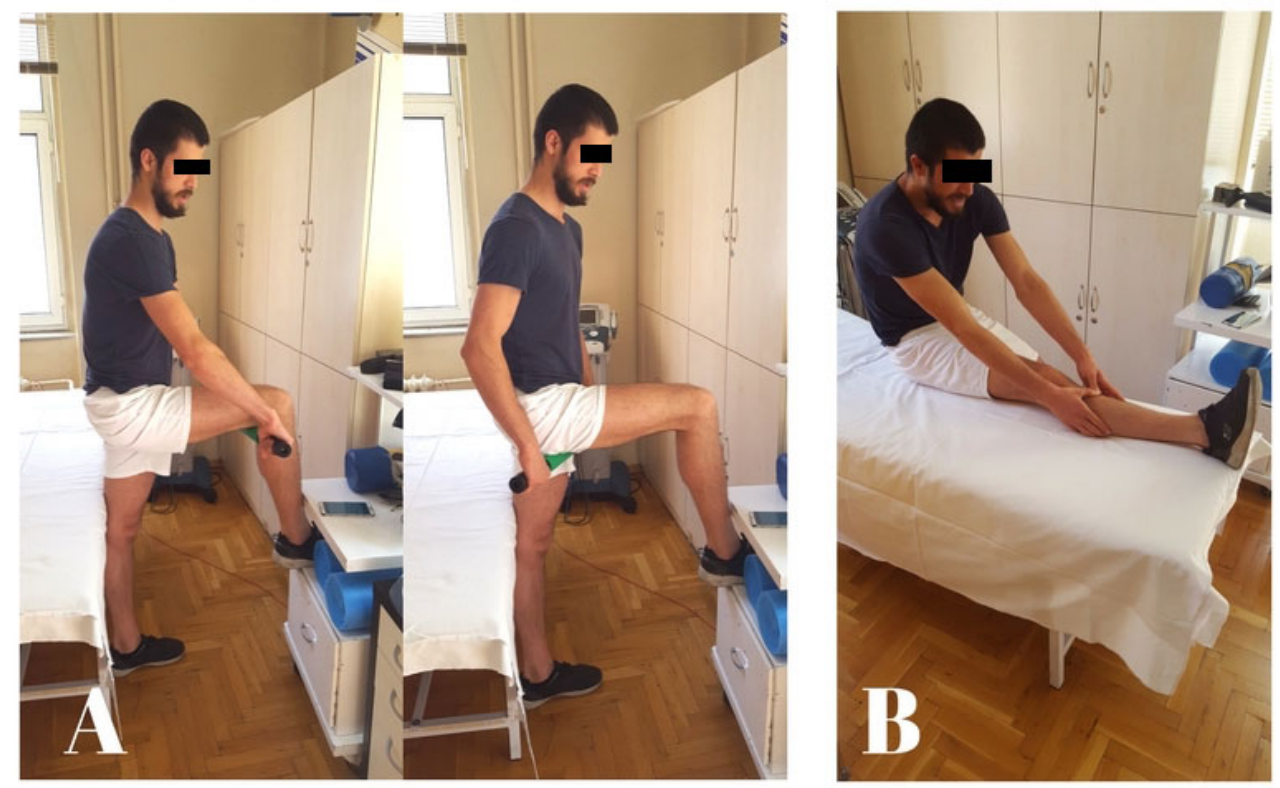

Figure 1. The self-myofascial release and static stretch procedures applied. (A) The beginning (left panel) and the end (right panel) of the myofascial release. (B) Patient position during the static stretching procedure.

\section{Isometric Testing Protocol}

Isometric strength tests were conducted using Cybex $^{\circledR} \quad$ (Humac Norm, CSMI, USA) dynamometer and knee torque-time traces were recorded. During measurements the subjects maintained an upright sitting position with 90 degrees of hip flexion. The center of the knee was aligned with the center of rotation of the dynamometer. The shin support was arranged according to the participant's leg length and fixed. The upper leg and trunk\&pelvis were fixed with belts (Fig. 2).

Unobstructed knee movement was assured in this secured condition and from full knee extension to $90^{\circ}$ the knee range of movement was introduced to the device. Gravity correction of the leg mass was performed. The knee angle was then set to $60^{\circ}$ and was kept fixed throughout the measurements. A submaximal knee extensor contraction for 5 seconds as a trial was followed by the testing protocol, which consisted of 3 subsequent maximal contractions performed for 5 seconds. A rest period of 6 seconds was allowed between each contraction.

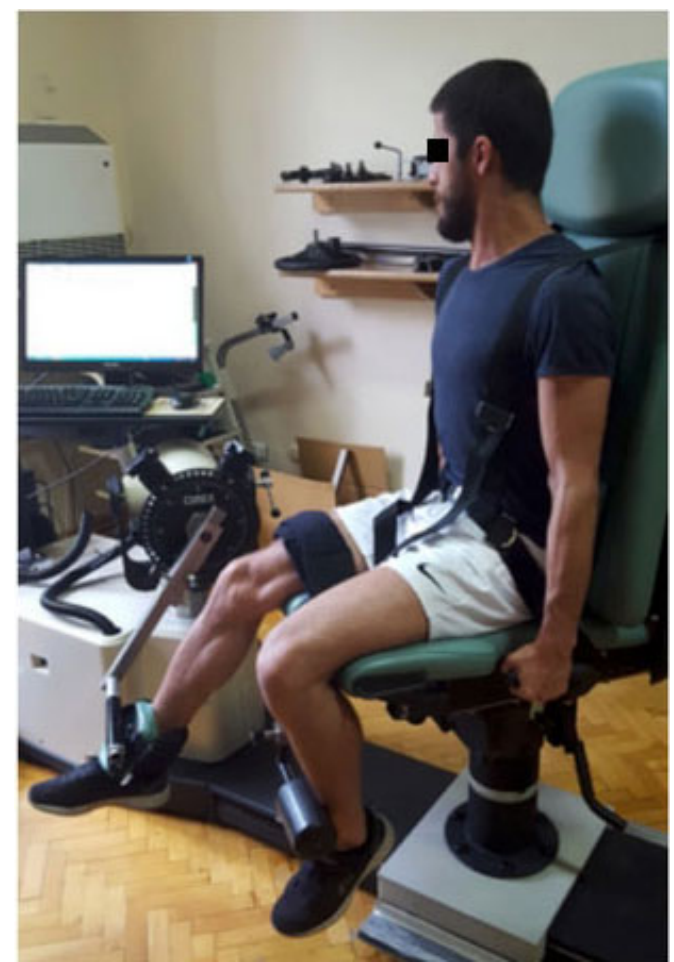

Figure 2. Isometric strength testing. 
After explanation of the test, the patients were asked to perform maximally strong contractions as fast as possible and hold for 5 seconds after the countdown on the screen. The same procedure was repeated with knee flexor contractions. After 3 contractions of extension, flexion was tested. The average of 3 measurements was included in the assessment.

\section{Statistical Anaylses}

The following experimental metrics were used in the analyses: Peak torque (an increase indicates elevated amplitude of force exerted at the joint), average torque (the average of torque exerted for 5 seconds, an increase indicates elevated force lump sum exerted at the joint), torque increase rate (slope of torque-time trace from start till peak torque, an increase indicates elevated speed of muscle contraction) and time to peak torque (an increase indicates reduced speed of muscle contraction). Note that these metrics normalized for body weight (BW) were also studied to secure the same interpretations.

Non-parametric tests were used because the data was not normally distributed. Wilcoxon S- rank test was used in order to detect the significant differences in the experimental metrics between pre and post conditions. A repeated measure ANOVA was used to detect the difference between the measurements. When the sphericity was violeted (Mauchly's test $<005$ ) the Greenhouse-Geisser correction vas considered. Intra-class Corelation Coefficient (ICC) $(2, \mathrm{k})$ and $95 \%$ Confidence Interval (CI) was calculated to assess variability across different sessions: Pre-intervention measurements made in the first and second visits of the participants' were included in the reliability assessment in order to evaluate the inter-session reliability of the metrics. Effect size (r) measurements were also performed. All tests were performed with SPSS (21.0 for Mac) and significance was set to $p<0.05$.

\section{RESULTS}

Baseline values for both testing sessions were similar ( $p>0.05)$. ICC revealed high values for torque related, and moderate values for time related variables (summarized in Table 2). Table 3 shows the experimental metrics calculated.

Table 2. Inter-session intra-class correlation coefficients measured

\begin{tabular}{|c|c|c|c|c|}
\hline & Metric & ICC & \%95 CI & $p$ \\
\hline \multirow{7}{*}{$\begin{array}{l}n \\
w \\
w \\
\tilde{s} \\
0 \\
0 \\
0 \\
\sigma\end{array}$} & Peak torque (N.m) & 0.821 & $0.578-0.925$ & $<0.001$ \\
\hline & Peak torque (BW\%) & 0.834 & $0.609-0.931$ & $<0.001$ \\
\hline & Average torque (N.m) & 0.790 & $0.505-0.912$ & $<0.001$ \\
\hline & Average torque (BW\%) & 0.814 & $0.531-0.922$ & $<0.001$ \\
\hline & Torque increase rate $\left(\mathrm{N} . \mathrm{m} . \mathrm{sec}^{-1}\right)$ & 0.799 & $0.509-0.917$ & $<0.001$ \\
\hline & Torque increase rate (BW\%) & 0.788 & $0.481-0.912$ & 0.001 \\
\hline & Time to peak torque (sec) & 0.631 & $0.103-0.848$ & 0.015 \\
\hline \multirow{7}{*}{ 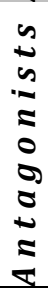 } & Peak torque (N.m) & 0.952 & $0.887-0.980$ & $<0.001$ \\
\hline & Peak torque (BW\%) & 0.937 & $0.850-0.974$ & $<0.001$ \\
\hline & Average torque (N.m) & 0.920 & $0.808-0.966$ & $<0.001$ \\
\hline & Average torque (BW\%) & 0.900 & $0.760-0.958$ & $<0.001$ \\
\hline & Torque increase rate $\left(\mathrm{N} . \mathrm{m} . \mathrm{sec}^{-1}\right)$ & 0.542 & $-0.137-0.812$ & 0.045 \\
\hline & Torque increase rate (BW\%) & 0.597 & $0.003-0.837$ & 0.025 \\
\hline & Time to peak torque (sec) & 0.580 & $-0.040-0.828$ & 0.030 \\
\hline
\end{tabular}


Table 3. Metrics calculated.

\begin{tabular}{|c|c|c|c|c|c|c|c|c|c|c|c|c|}
\hline \multirow{10}{*}{$\nabla$} & & \multicolumn{4}{|l|}{ Static Stretching } & \multicolumn{3}{|c|}{ Self-myofascial Release } & \multicolumn{4}{|c|}{ ANOVA ( Time ${ }^{*}$ Group) } \\
\hline & & Pre (mean $\pm s d)$ & $\begin{array}{l}\text { Post } \\
\text { (mean } \pm \text { sd) }\end{array}$ & $p^{*}$ & $\mathbf{r}$ & $\begin{array}{l}\text { Pre } \\
\text { (mean } \pm s d)\end{array}$ & $\begin{array}{l}\text { Post } \\
\text { (mean } \pm s d)\end{array}$ & $p^{*}$ & $r$ & $p^{* * *}$ & $\begin{array}{l}F(1, \\
42)\end{array}$ & $p^{4}$ \\
\hline & $\begin{array}{l}\text { Peak torque } \\
\text { (N.m) }\end{array}$ & $116.73 \pm 17.61$ & $120 \pm 17.61$ & 0.14 & -0.22 & $112.32 \pm 21.67$ & $116.45 \pm 22.55$ & 0.135 & $\begin{array}{l}- \\
0.23\end{array}$ & 0.188 & 0.070 & 0.793 \\
\hline & $\begin{array}{l}\text { Peak torque } \\
\text { (BW\%) }\end{array}$ & $152.95 \pm 24.83$ & $156.23 \pm 21.11$ & 0.231 & -0.18 & $146.95 \pm 28.27$ & $152.14 \pm 29.24$ & 0.125 & - & 0.168 & 0.194 & 0.662 \\
\hline & $\begin{array}{l}\text { Average torque } \\
\text { (N.m) }\end{array}$ & $101.32 \pm 16.68$ & $105.14 \pm 17.49$ & 0.099 & -0.25 & $97.18 \pm 18.57$ & $103.59 \pm 22.02$ & $0.030 *$ & $\overline{-}-3$ & 0.197 & 0.503 & 0.482 \\
\hline & $\begin{array}{l}\text { Average torque } \\
\text { (BW\%) }\end{array}$ & $132.68 \pm 22.85$ & $137.14 \pm 20.84$ & 0.091 & -0.25 & $126.82 \pm 24.59$ & $134.82 \pm 28.78$ & $0.031 *$ & - & 0.151 & 0.552 & 0.461 \\
\hline & $\begin{array}{l}\text { Torque increase } \\
\text { rate }\left(\mathrm{N} \cdot \mathrm{m}_{\mathrm{sec}} \mathrm{sec}^{-1}\right)\end{array}$ & $86.68 \pm 29.82$ & $102.64 \pm 31.28$ & $0.016^{*}$ & -0.36 & $86.55 \pm 43.46$ & $77.91 \pm 28.14$ & 0.330 & $-\overline{0.15}$ & 0.984 & 6.168 & $0.017^{\natural}$ \\
\hline & $\begin{array}{l}\text { Torque increase } \\
\text { rate (BW\%) }\end{array}$ & $113.14 \pm 38.9$ & $135.86 \pm 48.45$ & $0.015^{*}$ & -0.37 & $112.59 \pm 55.2$ & $101.82 \pm 37.37$ & 0.297 & - & 0.950 & 6.493 & $0.015^{q}$ \\
\hline & $\begin{array}{l}\text { Time to half peak } \\
\text { torque }(\mathrm{sec})\end{array}$ & $0.21 \pm 0.09$ & $0.18 \pm 0.11$ & 0.268 & -0.17 & $0.21 \pm 0.17$ & $0.2 \pm 0.11$ & 0.903 & $\begin{array}{l}- \\
0.02\end{array}$ & 0.877 & 0.097 & 0.758 \\
\hline & $\begin{array}{l}\text { Time to peak } \\
\text { torque }(\mathrm{sec})\end{array}$ & $1.85 \pm 0.64$ & $1.66 \pm 0.66$ & 0.291 & -0.16 & $1.94 \pm 0.78$ & $2.02 \pm 0.71$ & 0.733 & - & 0.566 & 1.835 & 0.183 \\
\hline & $\begin{array}{l}\text { Peak torque } \\
\text { (N.m) }\end{array}$ & $217.91 \pm 40.72$ & $226.23 \pm 41.73$ & 0.074 & -0.27 & $214.45 \pm 42.96$ & $219 \pm 51$ & 0.807 & $\overline{-}$ & 0.375 & 0.375 & 0.544 \\
\hline & $\begin{array}{l}\text { Peak torque } \\
(\mathrm{BW} \%)\end{array}$ & $283.27 \pm 46.15$ & $293.64 \pm 45.42$ & 0.092 & -0.25 & $279.05 \pm 50.63$ & $284.77 \pm 60.36$ & 0.688 & $\overline{-}-$ & 0.413 & 0.336 & 0.565 \\
\hline$\ddot{n}$ & $\begin{array}{l}\text { Average torque } \\
\text { (N.m) }\end{array}$ & $188.23 \pm 37.79$ & $197.41 \pm 37.89$ & $0.023^{*}$ & -0.34 & $184.91 \pm 39.25$ & $192.14 \pm 44.93$ & 0.144 & $-\overline{0.22}$ & 0.471 & 0.131 & 0.719 \\
\hline$\underset{0}{0}$ & $\begin{array}{l}\text { Average torque } \\
\text { (BW\%) }\end{array}$ & $244.45 \pm 42.31$ & $256.18 \pm 43.27$ & $0.025^{*}$ & -0.34 & $240.59 \pm 46.95$ & $249.77 \pm 53.85$ & 0.116 & - & 0.514 & 0.126 & 0.724 \\
\hline$\sigma$ & $\begin{array}{l}\text { Torque increase } \\
\text { rate }\left(\mathrm{N} \cdot \mathrm{m}_{\mathrm{sec}}{ }^{-1}\right)\end{array}$ & $123.59 \pm 56.81$ & $130.59 \pm 157.89$ & 0.372 & -0.13 & $121.32 \pm 50.54$ & $107.86 \pm 62.21$ & 0.291 & $\overline{-}-16$ & 0.862 & 0.310 & 0.581 \\
\hline & $\begin{array}{l}\text { Torque increase } \\
\text { rate (BW\%) }\end{array}$ & $161.32 \pm 78.61$ & $169.45 \pm 194.97$ & 0.372 & -0.13 & $158.91 \pm 68.24$ & $141.64 \pm 83.2$ & 0.299 & $\begin{array}{l}- \\
0.16\end{array}$ & 0.889 & 0.303 & 0.585 \\
\hline
\end{tabular}




\begin{tabular}{|c|c|c|c|c|c|c|c|c|c|c|c|}
\hline $\begin{array}{l}\text { Time to half peak } \\
\text { torque (sec) }\end{array}$ & $0.25 \pm 0.16$ & $0.2 \pm 0.08$ & 0.157 & -0.21 & $0.28 \pm 0.2$ & $0.21 \pm 0.09$ & 0.167 & $\begin{array}{l}- \\
0.21\end{array}$ & 0.588 & 0.074 & 0.787 \\
\hline $\begin{array}{l}\text { Time to peak } \\
\text { torque (sec) }\end{array}$ & $2.44 \pm 1.1$ & $2.88 \pm 1.19$ & 0.163 & -0.21 & $2.45 \pm 1.01$ & $2.86 \pm 1.05$ & 0.021* & $\overline{0}-\overline{1}$ & 0.967 & 0.011 & 0.918 \\
\hline
\end{tabular}

SD: Standard deviation, N.m: Newton-meter, BW: Body weight, sec: Second

$\mathrm{p}^{*}$ significance between pre and post treatment conditions, $\mathrm{p}^{* * *}$ significance between two pre conditions, $\mathrm{r}$ effect size. $\mathrm{p}^{\natural}$ significance within repeated measure ANOVA, time* group interaction effect 


\section{Effects of static stretch}

For the knee flexor contraction, SS caused a significant increase in torque increase rate and torque increase rate normalized for BW by $18.4 \% \quad(p=0.016)$ and $20.1 \% \quad(p=0.015)$, respectively, whereas for the remainder metrics no significant effects were shown $(p>0.05)$.

For the knee extensor contraction, SS caused a significant increase in average torque and average torque normalized for BW by $4.9 \%$ $(p=0.023)$ and $4.8 \% \quad(p=0.025)$, respectively, whereas for the remainder metrics no significant effects were shown $(p>0.05)$.

\section{Effects of self-myofascial release}

For the knee flexor contraction, SMR caused a significant increase in average torque and average torque normalized for BW by $6.6 \%$ $(p=0.03)$ and $6.3 \% \quad(p=0.031)$, respectively, whereas for the remainder metrics no significant effects were shown $(p>0.05)$. For the knee extensor contraction, SMR caused a significant increase in time to peak torque by $16.7 \%(p=0.021)$, whereas for the remainder metrics no significant effects were shown $(p>0.05)$. Effect size calculations revealed moderate practical significance for significant changes (Table 3).(21)

It should be noted that when analyzed with repeated measures ANOVA, there was statistically significant difference for group interaction effect (time*group) on agonists' torque increase rate $(\mathrm{F}(1,42)=6.168, \mathrm{p}=0.017)$ and \%BW $(F(1,42)=6.493, p=0.015)$ of this measure (Table 3).

\section{DISCUSSION}

The results showed that none of the interventions caused elevated peak torque exerted at the joint for neither the agonistic (knee flexor) nor antagonistic (knee extensor) action. For the agonistic action, SS caused elevated speed of muscle contraction, but no change in force exerted at the joint, whereas SMR did elevate knee flexor muscle's force lump sum exerted at the joint without affecting speed of muscle contraction. For the antagonistic action, SS did elevate knee extensor muscle's force lump sum exerted at the joint without affecting speed of muscle contraction. SMR only reduced speed of muscle contraction. However, both interventions imposed sizable effects. Overall, SMR affected force production and SS affected speed of contraction positively for the knee flexors and SS affected force production positively for the knee extensors. However, SMR has a negative effect on speed of contraction of the knee extensors.

As Behm et al. summarized in the systematic review, the average poststretching measurement time is 3-5 min in vast majority of the studies and tests conducted $>10$ minutes later yield typically statistically trivial effects on performance unless an extreme stretch protocol was used.(7) We have used a relatively comfortable (stretching that does not elicit pain or significant discomfort), only one selfstretching movement with moderate intensity unlike many other studies using either assisted,(22) combined assisted and self stretches,(23) or with more extreme (stretches at maximal tolerable pain limit) protocols.(24) This may explain why we observed a positive outcome after static stretching. We believe that this moderate intensity self-stretch coincides more with general practice of the population. Also the imposed stretch duration is important. Simic et al. reported minor to trivial negative effects of SS on peak force and peak torque for an SS total duration per muscle group $\leq 45$ seconds, likely negative effects for 46-90 seconds and certainly negative effects for $>90$ seconds.(13) The negative effect observed was significantly larger for isometric vs. dynamic strength tests and this was our rationale for using a single isometric test. Yet, isometric tests were focused solely on the agonistic muscle group. Presently, the total SS duration was 240 seconds, which yielded contrasting results showing a positive effect on the torque increase rate in agonistic action. Moreover, SS did positively affect also the antagonistic muscles leading to elevated force production. The amplitude of that effect approximating 5\% represents a moderate to large effect according 
to athletic performance tests.(25) Some positive effects were reported after SS in certain tasks such as jumping, cycling and sprinting, suggesting that improvements are task dependent.(9) Although we did not measure athletic performance during such dynamic tasks, the present increase in force lump sum suggest that possible improved function caused by SS may present itself also during isometric testing. It is of importance that the test-retest reliability of time dependent metrics such as time to peak torque or torque increase rate were lower than that of strength based measurements, thus these positive impacts on static stretching should be implemented carefully.

Monteiro et al.(26) investigated the effects of SMR applied on hamstring muscle group and measured the strength endurance of the knee extensors. They found a detrimental, dosedependent effect of foam rolling on repetition performance of the antagonists. MacDonald et al.(12) investigated the effects of foam rollers on recovery from exercise induced muscle damage. After a bout of intense physical activity, they measured soreness, degree of ROM, voluntary (e.g., maximal voluntary contraction (MVC)) and evoked (e.g., twitch force, and rate of force development) contractile properties and conducted dynamic performance tests with and without foam rolling. However, differently than the present study, the roller was applied to the entire lower extremity and for 20 minutes. Such SMR improved recovery (by reducing soreness), dynamic movements and ROM while causing no change in MVC and a substantial decrease in evoked contractile response (i.e., twitch force). Accordingly, the authors concluded that SMR helped recovery not at muscular level, but potentially by restoring passive non-contractile structures such as series elastic components. Moreover, although an elevated muscle activation was shown during recovery, this was ascribed to reduced soreness in muscles and less neural inhibition due to healthier connective tissues.(12) A roller-massager used on plantar flexor muscles increased their MVC, which was attributed to a possible increase in muscle temperature, phosphorylation of the myosin regulatory light chains or release of myofascial restrictions that are believed to occur after a heavy workout, tissue damage or in the trigger points.(8) On the other hand, there are studies, reporting no effects of SMR applied using foam rollers on different parameters of athletic performance. Healey et al.(3) after applying such SMR to the entire body showed no change in isometric squat force, jump height and agility. Sullivan et al.(27) showed no effects of SMR applied on the hamstrings on force and speed metrics. Therefore, SMR by foam rollers is typically considered to serve primarily for improving recovery. However, we tested healthy individuals with no injury, soreness or fascial restrictions and yet the average torque production performance of the agonists for 5 seconds did increase substantially, whereas the speed performance of the antagonists showed a decrease. This indicates that SMR does have an impact on performance. Additionally, the present findings achieved after a selective, short duration application suggested that this intervention had effects on contractile properties of both agonistic and antagonistic muscles.

Widespread effects of both interventions indicated that affected contractile properties were ascribable to epimuscular myofascial force transmission.(15) Central to this mechanism are myofascial loads that can affect sarcomere lengths. These loads include forces exerted by the muscle's extracellular matrix on muscle fibers via their mutual trans-sarcolemmal attachments,(28) and those that act on the muscle belly due muscle relative position changes in joint motion.(29) The latter is transmitted via collagen reinforced neurovascular tracts and compartmental connective tissues within and across muscle compartments and direct collagenous connections between adjacent muscles as well.(17) Externally imposed loads will also reach muscle fibers via the integral network of connective tissues. Pamuk et al.(18) showed that superficial mechanical loading imposed by kinesiotaping applied over the skin along the tibialis anterior causes substantial local tissue 
length changes not only within the targeted tissues, but also within the entire lower leg including the non-targeted synergistic and antagonistic muscles. The present SMR is an externally imposed loading not only along the line of action, but also transversely on the targeted hamstrings. However, the remainder upper leg muscles were not loaded directly. SMR effects could be explained by transmission of these externally imposed loads on those muscles. Although SS involves no external loading, it involves stretching of the hamstrings via joint extension. This leads to relative position changes with the knee flexors stretching e.g., the neurovascular tracts and providing stiff force transmission pathways. Therefore, a different mechanism of epimuscular myofascial force transmission is conceivable between the two interventions studied. Nevertheless, differences in epimuscular myofascial force transmission mechanism could explain the non-uniform effects of these two interventions shown. Unlike SS, MFR is a method that involves 'touch'. Therefore, additional neuro-physiological inhibitory effects are expected. However, the touch-inhibitory effect was not observed in the agonist muscle group, but in the antagonist group. Additionally, the reduced spinal reflex excitability caused by massage and stretching substantially recovered 2 minutes postintervention,(30) suggesting that neural factors were expected to become normal after the very first minutes of applications. Epimuscular myofascial force transmission can have a role in explaining our results, as myofascial loads can alter lengths of muscle spindles. Myofascial manipulations affect connective tissues substantially and due to such force transmission also a functional effect of optimized muscular force production is likely.

Time dependent metrics showed lower consistency between sessions. This limitation might be resulted from lower motivation of some of the participants to generate a rapid contraction ascribable to lack of verbal commands given during the tests. This might also be due to the highly sensitive attachment arm of the isokinetic device, detecting a smallest motion to start recording. Specific tests in new studies are indicated to overcome such possible causes of variability, as these metrics are important for our understanding of muscular function. We did not perform multiple isometric tests e.g. immediately after, $5 \mathrm{~min}$ after and 10 min after the interventions as we tried to avoid effects of fatigue which could be regarded as another limitation of this study. Further studies may investigate the histological alterations of the fascia and the muscle after varying amount of myofascial manipulations in order to understand local as well as global changes.

\section{CONCLUSION}

A bout of self-myofascial release and static stretching yielded differential effects in the targeted muscles. Both techniques also affected the antagonistic muscles. Moreover, not all effects were positive and the methods were not interchangeable. Athletes utilizing sustained isometric contraction (e.g., for postural control) more than explosive power might benefit from applying SMR to the agonist, and SS applied to the antagonist. However, an expectation of elevated peak force exertion was not supported by these techniques. Even a short bout of selfmyofascial manipulation applied to one muscle group may alter the contractile properties of the entire extremity.

\section{ACKNOWLEDGMENTS}

The authors have no conflicts of interest to disclose. The authors would like to thank Prof. Bulent Bayraktar for his guidance and mentorship, Bernard Tahirbegolli for his extensive help in statistical analyses, Ebru Kaya Mutlu for her helps in volunteers and Turker Sahinkaya for conducting the tests.

\section{REFERENCES}

1. Barnes MF. The basic science of myofascial release: morphologic change in connective tissue. J Bodyw Mov Ther. 1997;1(4):231-8.

2. Pavan PG, Stecco A, Stern R, et al. Painful connections: densification versus fibrosis of fascia. Curr Pain Headache Rep. 2014;18(8):441. 
3. Healey KC, Hatfield DL, Blanpied P, et al. The effects of myofascial release with foam rolling on performance. $J$ Strength Cond Res. 2014;28(1):61-8.

4. Langevin HM, Fox JR, Koptiuch C, et al. Reduced thoracolumbar fascia shear strain in human chronic low back pain. BMC Musculoskelet Disord. 2011;12(1):203.

5. Ajimsha MS, Al-Mudahka NR, Al-Madzhar JA. Effectiveness of myofascial release: Systematic review of randomized controlled trials. J Bodyw Mov Ther. 2015;19(1):102-12.

6. Schleip R. Fascial plasticity-a new neurobiological explanation: Part 1. J Bodyw Mov Ther. 2003;7(1):11-9.

7. Behm DG, Blazevich AJ, Kay AD, et al. Acute effects of muscle stretching on physical performance, range of motion, and injury incidence in healthy active individuals: a systematic review. Appl Physiol Nutr Metab. 2015;41(1):1-11.

8. Halperin I, Aboodarda SJ, Button DC, et al. Roller massager improves range of motion of plantar flexor muscles without subsequent decreases in force parameters. Int J Sports Phys Ther. 2014;9(1):92-102.

9. Kay AD, Blazevich AJ. Effect of acute static stretch on maximal muscle performance: a systematic review. Med Sci Sports Exerc. 2012;44(1):154-64.

10. MacDonald GZ, Penney MDH, Mullaley ME, et al. An acute bout of self-myofascial release increases range of motion without a subsequent decrease in muscle activation or force. J Strength Cond Res. 2013;27(3):812-21.

11. Jay K, Sundstrup E, Søndergaard SD, et al. Specific and cross over effects of massage for muscle soreness: randomized controlled trial. Int J Sports Phys Ther. 2014;9(1):82.

12. MacDonald GZ, Button DC, Drinkwater EJ, et al. Foam rolling as a recovery tool after an intense bout of physical activity. Med Sci Sports Exerc. 2014;46(1):13142.

13. Simic L, Sarabon N, Markovic G. Does pre - exercise static stretching inhibit maximal muscular performance? A meta - analytical review. Scand J Med Sci Sports. 2013;23(2):131-48.

14. Kidd RF. Why myofascial release will never be evidence-based. Int Musculoskelet Med. 2009;31(2):556.

15. Yucesoy CA. Epimuscular myofascial force transmission implies novel principles for muscular mechanics. Exerc Sport Sci Rev. 2010;38(3):128-34.

16. Yucesoy CA, Baan G, Huijing PA. Epimuscular myofascial force transmission occurs in the rat between the deep flexor muscles and their antagonistic muscles. $J$ Electromyogr Kinesiol. 2010;20(1):118-26.
17. Kaya CS, Temelli Y, Ates F, et al. Effects of intersynergistic mechanical interactions on the mechanical behaviour of activated spastic semitendinosus muscle of patients with cerebral palsy. J Mech Behav Biomed Mater. 2018;77:78-84.

18. Pamuk U, Yucesoy CA. MRI analyses show that kinesio taping affects much more than just the targeted superficial tissues and causes heterogeneous deformations within the whole limb. J Biomech. 2015;48(16):4262-70.

19. Cavanaugh MT, Döweling A, Young JD, et al. An acute session of roller massage prolongs voluntary torque development and diminishes evoked pain. Eur J Appl Physiol. 2017;117(1):109-17.

20. Robertson M. Self-myofascial release purpose, methods and techniques. Indianapolis, IN Robertson Training Systems. 2008.

21. Cohen J. Statistical power analysis. Curr Dir Psychol Sci. 1992;1(3):98-101.

22. Balle SS, Magnusson SP, McHugh MP. Effects of contract-relax versus static stretching on strength loss and the length-tension relationship. Scand J Med Sci Sports. 2015;25(6):764-9.

23. Nelson AG, Allen JD, Cornwell A, et al. Inhibition of maximal voluntary isometric torque production by acute stretching is joint-angle specific. Res $Q$ Exerc Sport. 2001;72(1):68-70.

24. Fowles JR, Sale DG, MacDougall JD. Reduced strength after passive stretch of the human plantarflexors. J Appl Physiol. 2000;89(3):1179-88.

25. Hopkins WG. How to interpret changes in an athletic performance test. Sportscience. 2004;8(1):1-7.

26. Monteiro ER, Škarabot J, Vigotsky AD, et al. Maximum Repetition Performance After Different Antagonist Foam Rolling Volumes In The Inter - Set Rest Period. Int J Sports Phys Ther. 2017;12(1):76.

27. Sullivan KM, Silvey DBJ, Button DC, et al. Roller massager application to the hamstrings increases sit and - reach range of motion within five to ten seconds without performance impairments. Int J Sports Phys Ther. 2013;8(3):228.

28. Berthier C, Blaineau S. Supramolecular organization of the subsarcolemmal cytoskeleton of adult skeletal muscle fibers. A review. Biol Cell. 1997;89(7):413-34.

29. Maas H, Baan GC, Huijing PA, et al. The relative position of EDL muscle affects the length of sarcomeres within muscle fibers: experimental results and finite-element modeling. J Biomech Eng. 2003;125(5):745-53.

30.Behm DG, Peach A, Maddigan M, et al. Massage and stretching reduce spinal reflex excitability without affecting twitch contractile properties. J Electromyogr Kinesiol. 2013;23(5):1215-21. 